\title{
Research on the Effect Path of Institutional Environment to Internal Control
}

\author{
Jing Zhang ${ }^{1, *}$ and Jingwen Wang ${ }^{1}$ \\ ${ }^{1}$ School of Accounting, Jilin University of Finance \& Economics, Changchun, Jilin 10117, China \\ *Corresponding author.Email:44898165@qq.com
}

\begin{abstract}
Based on China's economic transition period and existing research results, this paper analyzes the mechanism and the path of the institutional environment to internal control of enterprises, which concludes three dimensions of political environment, economic conditions and cultural construction. According to the national conditions, it also probes the combined effect of institutional environment and property rights on internal control under different property rights conditions. Through the paper's research, we can further clarify the effect of institutional environment and property rights on internal control mechanism, which also enriches research findings of institutional environment and internal control. It provides certain reference significance for prospective users.

Keywords: Institutional Environment; Nature of Property Rights; Internal Control; Function Path
\end{abstract}

\section{INTRODUCTION}

Cases that damaged the interests of the investors are not uncommon worldwide when problems occurred with the internal control of the enterprise. In 2002, the United States promulgated the SOX act to strengthen the supervision for internal control, which meant that the government began to attach the importance to corporate internal control. In 2008, China was led by the Ministry of Finance and other five ministries and commissions gradually implemented the establishment of an internal control standard system, which promulgated a series of supporting documents such as the "Basic Standards for Enterprise Internal Control" and "Supporting Guidance for Enterprise Internal Control", indicating the gradual formation of internal control standards for domestic enterprises. These landmark events not only mean that corporate internal control has entered into the scope of government supervision as well as become the focus and hot spot of global attention gradually, but also that the relationship between government and enterprise has gradually become a key factor in the implementation and construction of the internal control.

A distinctive feature of China's current transitional economic background is that administrative power acts on the national economy. Despite the continuous improvement of the institutional environment, the government still determines policy formulation and resource allocation to a large extent. In order to obtain better policies and resources, companies usually employ methods such as hiring government officials with political background or letting senior executives take the initiative to participate in politics. Connect with the government. This kind of political connection is also a common phenomenon in the economic development of various countries. At present, there are not many researches on the relationship between the nature of property rights and the internal control of enterprises in academic circles, but whether the nature of property rights promotes or hinders the construction of internal control of enterprises is not conclusive.

Due to the lack of market competition, more social responsibilities, more administrative intervention, and soft budget constraints for state-owned holding companies, it is difficult to effectively verify internal control, while private companies are often able to make decisions more autonomously when facing government control. To better demonstrate the economic effects of the institutional environment on internal control. At the same time, compared with state-owned enterprises, private enterprises face greater policy changes, backward management strategies, insufficient innovation capabilities, financial difficulties, and lack of risk control mechanisms, resulting in frequent internal control failures and even operating difficulties. Therefore, it is undoubtedly more urgent and realistic to conduct internal control research on holding companies with different property rights.

Motivation and motivation forms purpose need to be generated. Combining the evolution of internal control, we can see that, although in form, internal control is a requirement of the legal system and government departments, in essence, the establishment and development of internal control has always been centered on one purpose to ensure the reliability of financial statements. To meet the needs of stakeholders, especially shareholders. The form of internal control is purchased by the enterprise, but its essence is the decision-making behavior of shareholders. Ownership structure is a collection of the proportion of corporate shareholders, their mutual relationships, and the distribution of rights and obligations. Different ownership structures will cause shareholders to form different needs for internal control audit services. The shareholding structure internally affects 
the enterprise's internal control audit service demand, at the same time, this demand will also be affected by the external market environment, especially the degree of market competition. Key factors such as constraints and bankruptcy risks will have obvious impacts. Shareholders can identify the company's own situation and seek appropriate internal control audit services.

In summary, how does the institutional environment affect the construction and development of the company's internal control? In companies with different property rights, are there differences in the role of the institutional environment in the construction of internal control? This paper analyzes those issues carefully.

\section{ANALYSIS OF THE ROLE OF THE INSTITUTIONAL ENVIRONMENT ON THE INTERNAL CONTROL MECHANISM}

Although administrative forces will affect the operations of enterprises, especially the central enterprises and local governments control companies. The existing papers also found that the political environment, economic conditions and cultural construction and other institutional conditions will affect most accounting and financial behavior of enterprises. The survival and operating performance of a company largely depends on the management of corporate politics and operational risk[1]. The political system and operational risk management of the company have been and will continue to be the key factors that determine the rise and fall of a company. The formulation of relevant economic systems and the introduction of reform measures have played a positive role in promoting the further improvement of corporate financial management[2]. Based on the reality of China's transitional economy, proposed that the impact on the economic environment[3]. While the internal control system is evolving, the internal control system also reacts to the impact of the economic environment. Through the design and operation of the internal control system, it continuously promotes the sustainable development of the economy; a better external system environment helps[4]. To promote local government holding companies to strengthen internal control construction and improve the quality of internal control. Under the development model of government-led internal control construction, network and policy-oriented media attention can improve the quality of internal control of listed companies.

Therefore, a better external institutional environment is helpful to promote the development of internal control construction of enterprises, and based on my country's market conditions, the institutional environment can be refined into three aspects: political environment, economic conditions, and cultural construction.

\subsection{Political environment}

The demand and supply requirements of accounting audit are vary from the multiple of political institutional structures[5]. On the one hand, a good political system structure requires high-quality accounting information disclosure and audit supervision as a guarantee. On the other hand, a good political system structure can create a good environment for the development of accounting auditing and improve the supply capacity of accounting auditing. Political culture affects the basic attitude of information users to public sector financial management information disclosure, and affects views on whether a more informative accounting system is needed who used the information. Political democratization is the driving force behind the development of modern national auditing. National auditing is not only a necessary means to achieve political democracy, but also an inherent requirement of political democracy[6].

Under different political system structures, the government has different requirements and focuses on the allocation and management of various economic resources. The political system structure is different, the accounting audit goal is also different. For example, under the planned economy system, the government is the plan maker and the main user of accounting information. Therefore, the goal of accounting is to meet the requirements of the government's plan management. Under the conditions of a market economy, the state's allocation of economic resources mainly depends on the market. Investors are the main users of accounting information, and the goal of accounting is naturally to meet the needs of investors.

At first, the Third Plenary Session of the Eighteenth Central Committee of the Party decided to spend to improve the credibility of the government and steadily promote government performance management, emphasizing the improvement and development of the socialist system with Chinese characteristics, and the promotion of reforms in the political system. This required companies to establish and improve government performance reporting systems and information disclosure in real time[7]. At the same time, the better the corporate performance supervision system, the higher the quality of corporate internal control could be.

\subsection{Economic conditions}

Since the advent of trading, the economic activities have been constantly evolving. In recent years, the economy has begun to develop in the globalization trend, along with the progress of the times, the momentum of economic development has become more and more fierce than before. However, the faster the economy develops, the more messy it will appear in some aspects, and the trend of the economy is prone to risks and various uncontrollable factors.

When the relationship between the government and the market is relatively close, on the one hand, enterprises enjoy the financing concessions brought by the government, and on the other hand, they also undertake the realistic task of driving economic development. Investment decisions are susceptible to government intervention. According to the theory of financing constraints, the 
financing ability of an enterprise determines the level of investment. From the perspective of the source of investment funds, effective internal control can signal to fund providers (such as banks) that the project is in good condition and investment risks are controllable. The internal control situation judges whether to provide loans for corporate investment projects; when the institutional environment is poor, the government may intervene in corporate lending behavior, or even guarantee them, reducing the reference role of internal control to fund providers, and also reducing Its inhibitory effect on overinvestment. From the perspective of investment funds, good internal control has higher requirements for risk assessment, and can provide managers with risk information related to investment projects. Managers can make corresponding investment decisions based on the information provided by internal control. When the institutional environment is poor, managers are subject to government intervention or even make investment decisions that are not conducive to the long-term development of the enterprise, ignoring internal control's judgment on investment feasibility, thereby reducing the advisory role of internal control.

Secondly, as a country in economic transition, companies must always pay attention to economic and market information, so as to keep abreast of market dynamics, ensure that corporate finance is in a reasonable and compliant premise, improve capital utilization efficiency, and be more efficient and high-quality to enable stable operations of the company, thereby strengthening the core of the company Competitiveness. Internal control plays a key role in the above circumstances. Therefore, enterprises will disclose the internal information of enterprises in a timely manner by improving the authenticity of accounting and financial data, so as to maximize the role of internal control construction.

Finally, the brand new economic condition, relevant government supervisors and regulatory agencies usually promote and restrict the construction of internal control of enterprises.

Therefore, the construction of internal control of enterprises will also be closely watched by relevant government supervisors and regulatory authorities.

\subsection{Cultural construction}

Furthermore, media attention has become a favorable passageway for the disclosure, collection and diffusion of corporate internal control information, which influenced the reputations of politicians, managers, and corporate executives in the apprehension of shareholders and future employers [8].

Accordingly, when a company receives a high degree of media attention, it is more likely to be exposed to the company's internal control behavior, which in turn attracts the attention of the administrative supervision department. At the same time, under the background of this kind of supervision system, the standardization of internal control of enterprises will be paid more attention, and the quality of internal control will be higher.

Therefore, this paper believes that the institutional environment of various regions will help improve the quality of internal control of enterprises, and that the more civilized the political environment, the more complete the economic condition construction system, and the more detailed the cultural construction, the higher the quality of internal control of the enterprise.

In many cases of financial fraud in listed companies, the media has played a vital role. More listed companies have actively improved the company's internal control system after media attention. The media as an external governance mechanism plays a role in corporate governance and internal control. The role has been recognized by more and more experts and scholars at home and abroad. The essence of the internal control system is risk management. The control environment directly affects the effectiveness of the internal control system. Media supervision is an important external mechanism to compensate for the lack of judicial protection. Nowadays, it is important to financial development and improve corporate governance. The role of the media plays an active role in improving the level of corporate governance and protecting the rights and interests of investors. The institutional environment in various places will help improve the quality of internal control of enterprises, and the more civilized the political environment, the more complete the economic conditions construction system, and the more detailed the cultural construction, the higher the quality of internal control of the enterprise.

\section{ANALYSIS OF THE PATH OF THE JOINT EFFECT OF THE INSTITUTIONAL ENVIRONMENT AND THE NATURE OF PROPERTY RIGHTS ON INTERNAL CONTROL}

According to the above analysis, the external institutional environment of the enterprise has a positive effect on the quality of internal control of the enterprise. However, the nature of the actual controller's property rights may have differences in the quality of internal control of the enterprise.

\subsection{The motivation for the construction of enterprise internal control}

Although the governance structure and regulatory conditions of listed companies restructured from stateowned enterprises have undergone great changes, the government controls them and still has the ability to influence the decisions and behaviors of these companies based on consideration of other objectives. Unlike non state-owned enterprises, the incentive and behaviors of the government have an important impact on state-owned 
listed companies. For example, studies have found that one of the main problems of early state-owned enterprises was that they assumed multiple goals of the government, such as economic development strategy, employment, taxation, Social stability and so on have caused policy burdens on state-owned enterprises. In recent years, with the gradual expansion of Chinese companies and the turbulence of the international market environment, a series of fraud cases such as Enron in the United States at the beginning of this century, the financial crisis triggered by the US subprime mortgage crisis, and the risk of business operations of Chinese companies Gradually, the company's risk control has begun to become a serious problem before us. Therefore, managing and controlling the risks of company development through the construction of an internal control system. Establishing and perfecting a modern corporate system have become the core of the work of my country's government authorities and market supervision departments in recent years. For this reason, the relevant departments try to promote the state-owned holding company to strengthen the construction of internal control and play its role as an example, so as to lead Chinese companies to realize the improvement of the level of internal control construction as a whole.

\subsection{The influence of hierarchical relationship on the construction of internal control}

The SASAC, which controls central SOEs, is higher than the local SASAC, which controls local state-owned enterprises, both in terms of its ability to deploy various resources and powers. At the same time, the senior management of government departments and companies controlled by the government have administrative levels. For promotion reasons, these government departments and the senior management of companies controlled by the government have the motivation to build good internal controls. In terms of professional knowledge, regulatory level, and talent reserves, the central SASAC, the Ministry of Finance and other departments are better than the local SASAC and competent departments. Accordingly, the central competent departments such as the SASAC, the Ministry of Finance, and the China Securities Regulatory Commission have the professional ability to do so. Actively promote the construction of internal control of enterprises controlled by the central government. However, local SASAC and other government departments have difficulty in guiding local government holding companies to carry out internal control construction due to limitations in professional knowledge and regulatory levels. They will follow and imitate central government-controlled companies to promote internal control. Construction and improvement. Therefore, in terms of internal control construction, local government holding companies may be "half a beat" slower than state-owned holding companies, resulting in lower quality of internal control of local government-controlled companies than state-owned holding companies. Similarly, the lower the level of government-controlled companies, the lower the value, which reflects the market's perception of this company's "level".

\subsection{The influence of administrative intervention on the construction of internal control of non-government holding companies}

Of course, administrative intervention forces will also have an impact on non-government-controlled companies, and may even guide them to obtain profits through non-market means, thereby not focusing on operations and operational risks, but this impact will be relatively small. The nongovernment-controlled companies stand their own operating risks, and there is no possibility that governments at all levels will be the last "saviors" or "redeemers" to save them, which means that the failure of governmentcontrolled companies will be paid by the state, while the failure of non-government-controlled companies will be borned by the shareholders themselves. Therefore, in terms of risk control, non-government controlled companies have a more urgent need. In order to control risks, nongovernment-controlled companies will actively improve internal control from all aspects according to the market environment and the actual development of the company, and control various risks in the company's development, including, (1) Actively recruit relevant professionals. In order to improve the company's professional level of risk management and control; (2) pay attention to the advanced management experience and measures of risk management in the same industry at home and abroad, and learn or imitate; (3) improve the company's internal environment, which is an important part of risk management and control measures. Implement and provide corresponding organizational structure, etc. In this way, when central enterprises gradually improve their internal control, local government-controlled companies mainly conduct this influence through the government's hierarchical structure, while non-government-controlled companies may base on the requirements of the regulatory authorities and the actual needs of the company, actively pass the Study and other methods to actively improve the company's internal control. This initiative may enable non-governmentcontrolled companies to keep up with the internal control construction of central enterprises so that the difference between the company's internal control and central enterprises is small or even not obvious.

Therefore, this paper believes that if other conditions being equal, the internal control quality of state-controlled central enterprises is higher than that of local governmentcontrolled enterprises. At the same time, when other conditions remain, the difference in internal control levels between non state-owned and state-owned enterprises is not obvious. 


\section{CONCLUSION}

This paper analyzes the mechanism and path of the institutional environment on the internal control of enterprises from the three dimensions of political environment, economic conditions and social environment, which finds the following conclusions: (1) The institutional conditions in various places will help improve the quality of internal control of enterprises. And the more civilized the political environment, the more consummate the economic conditions construction system, and the more detailed the cultural construction is, the higher the quality of internal control of the enterprise could be. (2) Other conditions being equal, the internal control quality of statecontrolled central enterprises is higher than that of local government-controlled enterprises. At the same time, when other conditions remain, the difference in internal control levels between non-state-owned and state-owned enterprises is not obvious.

\section{REFERENCES}

[1] Jena Vaibhav Kumar. "Carleman estimate for ultrahyperbolic operators and improved interior control for wave equations." Journal of Differential Equations 302.(2021): DOI:10.1016/J.JDE.2021.08.034.

[2] Ahmad Daud, et al. "Variationally Improved Bézier Surfaces with Shifted Knots." Advances in Mathematical Physics 2021.(2021):

DOI:10.1155/2021/9978633.

[3] Hyeesoo (Sally) Chung, et al. "Market reactions to the internal control reporting presentation format:

combined vs separate audit reports." Managerial
Auditing Journal 36.7(2021): DOI:10.1108/MAJ-122020-2951.

[4] Wang Jiacan, Hu Liangzhang,and Gong Daqing. "Modeling the Internal Control Constraint of University Research Funding System.” Discrete Dynamics in Nature and Society 2021.(2021):

DOI:10.1155/2021/3412189.

[5] Jiahui Meng. "Research on the internal control information disclosure of listed companies".

Proceedings of 2nd International Conference on Schooling Advances, Microeconomics and Management Science (SAMMS 2021).Ed. Proceedings of 2nd International Conference on Schooling Advances, Microeconomics and Management Science (SAMMS 2021), 2021, 192-196.(In Chinese)

[6] Yang D.P., et al. “Adaptive nonlinear ANC system based on time-domain signal reconstruction technology." Mechanical Systems and Signal Processing 162.(2022): DOI:10.1016/J.YMSSP.2021.108056.

[7] Min Wu. "On the Internal Control and Audit of Computer Accounting." Journal of Physics: Conference Series 1915.4(2021): DOI:10.1088/17426596/1915/4/042007.

[8] Muxiao Li, et al. "An investigation into high-speed train interior noise with operational transfer path analysis method.” Railway Engineering Science. prepublish (2021): DOI:10.1007/S40534-021-00235-0. 